\title{
KNOWLEDGE LIFE CYCLE AND ITS APPLICATION IN AUTOMOTIVE INDUSTRY
}

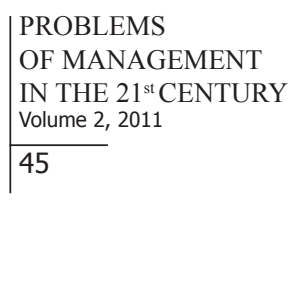

\author{
Jana Ďurišová \\ University of Pardubice, Pardubice, Czech Republic \\ E-mail: Jana.Durisova@upce.cz
}

\begin{abstract}
Knowledge management (KM) is attracting considerable attention as many organizations realize that they compete in a knowledge economy. Therefore, a key source of sustainable competitive advantage relies on managing knowledge. The vast majority of the existing frameworks in KM efforts focus on knowledge processes that takes place during the so-called "knowledge life-cycle" (KLC). Analysis of knowledge flow should always cover the entire life cycle of knowledge, from its formation, through saving and using, to its end. Companies that want to develop and use knowledge most effectively and profitably should begin to treat it differently according to the stages of the knowledge life-cycle. The purpose of this paper is to compare main concepts of the knowledge life cycle and to introduce a possibility of analyzing knowledge flow in practice, particularly in the automotive industry. The first section introduces knowledge management in organizations. Thereafter, a list of main concepts of knowledge life cycle is presented. Most of the concepts are similar and describe KLC as a process that consists of several stages in hierarchical order. Authors usually add particular steps that differ from others, such as individual and group learning from knowledge, obtaining value from knowledge, or knowledge disposal at the end of the process. Although KLC models have already been usefully developed as a tool for thinking about products and technology, a case study presenting knowledge flow during all stages of life cycle in automobile industry is missing. Therefore, the potential of analyzing knowledge flow in automotive industry is outlined as this field is the subject of author's research. The final section summarizes important contributions and insights for future research.
\end{abstract}

Key words: knowledge, knowledge management, knowledge life cycle, automotive industry.

\section{Introduction}

Over the last few decades the market place has completely changed with market boundaries having been eliminated by internet capabilities, advancements in technology, ecommerce and globalization. Moreover, companies face other challenges such as shortened product lifecycles and global competition. These factors have introduced rapid changes in competitive strategy development. All companies make decisions that affect their competitive position, effectiveness and profitability in the long run.

Attention to knowledge management is growing as many organizations are realizing that they compete in increasingly knowledge-intensive markets (Probst, 1998). Traditional resources related to the industrial period such as land, labor and capital, are not the only resources relevant in the transition to a knowledge driven society and knowledge economy (Bureš, 2005). In the knowledge economy, a key source of sustainable competitive advantage relies on the ability to create, share, and utilize knowledge ( $\mathrm{Wu}, 2007)$; therefore, knowledge is becoming one of the strategic resources of organizations for the $21^{\text {st }}$ Century.

The following critical aspects must be borne in mind when considering knowledge management according to a senior IT manager in an automotive company, in 1997 (Siemieniuch, 1999): 
PROBLEMS

OF MANAGEMENT

IN THE $21^{\text {st }}$ CENTURY

Volume 2, 2011

'In 50 years' time, we will be designing products we don't know, incorporating materials which haven't been invented, made in processes yet to be defined, by people we have not yet recruited. Under these circumstances, all we can carry forward is our knowledge, and our knowledge of how to improve our knowledge."

According to Nonaka (1995), in an economy where "the only certainty is uncertainty, the only reliable source of lasting competitive advantage is knowledge". Moreover, it is the only resource, whose value does not decrease, but increases with usage (Glaser, 1998), a factor that ensures stable growth performance and competitive advantage.

The purpose of this paper is to compare main concepts of the knowledge life cycle and to introduce a possibility of analyzing knowledge flow in practice, particularly in the automotive industry.

The paper is structured as follows: the first section introduces knowledge management in organizations. In the next section, a list of main concepts of knowledge life cycle is presented. Thereafter, a possibility of analyzing knowledge flow in the automotive industry is discussed. Finally, the conclusion summarizes important contributions and insights for future research.

\section{Theoretical Background}

The goal of knowledge management $(\mathrm{KM})$ is to provide the right information to the right person at the right time. Knowledge management includes those efforts designed to convert and connect KM capabilities (O'Leary, 1998): converting individual to group-available knowledge, converting data to knowledge, converting text to knowledge, connecting people to knowledge, connecting knowledge to knowledge, connecting people to people, and connecting knowledge to people. Organizations use KM for a number of reasons, including environmental pressures, technological advancements, and the ability to create valuable information (O'Leary, 1998). Managing knowledge is a core competence of the "smart" organization, hence managers should know where to find it and what to do with it (Mezgár, 2006).

There are different perceptions of the term of knowledge and its different classifications, which bring number of definitions. It is therefore essential to make a proper distinction between the terms data, information, knowledge, and wisdom. These terms are described and examples are given in table 1 .

The most common categorization of knowledge is that according to Polanyi (2009), where the knowledge is divided into two groups - explicit and tacit. Explicit knowledge is formal, systematic, expressed externally, and thus easy to capture, store, and communicate. It can be packaged as information and can be found in the documents of an organization, e.g. reports, articles, manuals, patents, pictures, images, video, software (Borghoff, 1997). Tacit knowledge is personal knowledge, a combination of individual experience and intuition, and cannot be expressed externally. Therefore, the organization's ability to capture and communicate it is heavily dependent on the individual owner's commitment to the organization (Mezgár, 2006). Sometime wisdom is considered as a tacit knowledge (Draghici, 2008). Also implicit knowledge definition should be defined. Implicit knowledge is knowledge that can be expressed externally when needed, but currently exists internally (in the worker's head). 
Table 1. Data, information, knowledge, wisdom.

\begin{tabular}{|l|l|l|l|}
\hline Terms & \multicolumn{1}{|c|}{ Description ${ }^{1}$} & \multicolumn{1}{c|}{ Guide } & \multicolumn{1}{c|}{ Examples } \\
\hline Data & $\begin{array}{l}\text { Data are independent, isolated } \\
\text { measurements, characters, numerical } \\
\text { characters, and symbols. }\end{array}$ & $\begin{array}{l}\text { We know that we have } \\
\text { something. }\end{array}$ & $\begin{array}{l}\text { Car sales figures during several years } \\
\text { and period of economic crisis. } \\
\text { (We have basic elements with no ex- } \\
\text { plicit context, their purpose is unclear.) }\end{array}$ \\
\hline Information & $\begin{array}{l}\text { Information is data that are included in } \\
\text { context that makes sense; it is data } \\
\text { endowed with relevance and purpose. }\end{array}$ & $\begin{array}{l}\text { We know what we } \\
\text { have and how to } \\
\text { use it. }\end{array}$ & $\begin{array}{l}\text { We know how to evaluate figures using } \\
\text { charts. } \\
\text { (We know what to do with basic ele- } \\
\text { ment, we can use manual, recipe etc.; } \\
\text { context is more specific.) }\end{array}$ \\
\hline Knowledge & $\begin{array}{l}\text { Knowledge is information combined with } \\
\text { experience, context, interpretation, and } \\
\text { reflection. }\end{array}$ & $\begin{array}{l}\text { We know what we } \\
\text { have, how to use it, } \\
\text { and we can do it. }\end{array}$ & $\begin{array}{l}\text { We can say that during the economic } \\
\text { risis car sales decreased significantly. } \\
\text { (Knowledge is a coordinated process, } \\
\text { has concrete result.) }\end{array}$ \\
\hline Wisdom & $\begin{array}{l}\text { Wisdom is knowledge combined with } \\
\text { learning, insights, and judgmental abili- } \\
\text { ties. It cannot be created like data and } \\
\text { information, and it cannot be shared with } \\
\text { others like knowledge. }\end{array}$ & $\begin{array}{l}\text { We know what, how, } \\
\text { we can, and we know } \\
\text { why we do this. }\end{array}$ & $\begin{array}{l}\text { We know exactly why it is evaluated that } \\
\text { way. We also know that it is possible to } \\
\text { slow down this decrease in sales using } \\
\text { "scrap page incentive" etc. } \\
\text { (We know exactly why this and why we } \\
\text { do it this way.) }\end{array}$ \\
\hline
\end{tabular}

Companies that want to develop and use knowledge most effectively and profitably, should begin to treat knowledge differently according to the stages of its life cycle. The analysis of the knowledge life cycle should determine the main flow of knowledge, its direction, and place of origin, strength and the participants involved in the flow. This should always cover the entire life cycle of knowledge, from its formation (creation, purchase, acquisition), through registration/saving, sharing/use, to its end (updates/replacement of new knowledge, retirement). Knowledge process then creates a circle around mentioned steps (see figure 1).

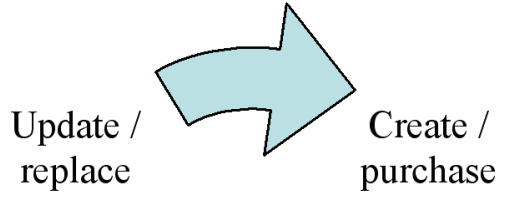<smiles>C1CCCCCC1</smiles><smiles>C1CCCCC1</smiles>

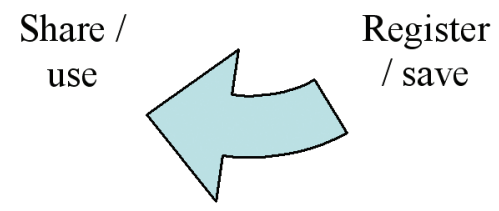

Figure 1: The knowledge process. 
PROBLEMS

OF MANAGEMENT

IN THE $21^{\text {st }}$ CENTURY

Volume 2, 2011

48

Due to the fact that there are plenty of models for KM implementation ${ }^{1}$, each organization can choose the most suitable model. It must be mentioned, that knowledge-management tools are not universally applicable; different tools are required at different stages of the knowledge life cycle (Birkinshaw, 2002).

As knowledge moves through the life cycle, the speed of progress varies enormously from one case to another. Birkinshaw (2002) determined factors that can accelerate or slow down the rate at which knowledge passes through the life cycle. Those factors that can speed up the rate are: ability of competitors to obtain the knowledge, natural leakage when sharing knowledge, and deliberate codification and diffusion by a company. On the other hand, the extent to which intellectual property rights are established, and the tacit nature of some knowledge (which resists codification) are factors which slow down the rate of transmission.

\section{Concepts of Knowledge Life Cycle}

The vast majority of the existing frameworks in KM efforts focus on the knowledge processes with stages in hierarchical order. According to Probst (1998), directly knowledgerelated activities are represented by "the building blocks" of knowledge management; these are: identification, acquisition, development, distribution, preservation, and use of knowledge. According to Wiig (1997), KM is split into four core activities: review, conceptualize, reflect, and act. Acting consist of developing knowledge (buying it, learning programs, machine learning on databases), distributing (to the points of action, manuals, network connections), combining (find synergies, reuse existing knowledge), and consolidating (prevent knowledge from disappearing, tutoring programs, knowledge transfer programs). APQC (1997) depicts the knowledge life cycle within organization and identifies key factors that support it. According to this work, the knowledge life cycle starts with finding and gathering knowledge and ends with their adaptation and application of knowledge to new situations. Fischer (2001) considers KM as a cyclic process involving three related activities: creation, integration, and dissemination. Becerra-Fernandez et al. (Sağsan, 2006) present stages of knowledge as knowledge discovery, capture, sharing, and application. Ribière (2008) assesses knowledge flows through knowledge creation (discovery, capture), knowledge storage (retention, organization), knowledge transfer (sharing, distribution), and knowledge use/maintenance. Draghici (2008) describes KLC as creation, codification, transfer, and use of knowledge. Apostolou (1999) prefer four core processes of KM, namely: generating, organizing, developing and distribution. Awad and Ghaziri (2004) present their Knowledge Life Cycle as "4-processes view" as well, which consists of knowledge capturing (data entry, scanning, voice input, interviewing, brainstorming), organizing (cataloguing, indexing, filtering, linking, codifying), refining (contextualizing, collaborating, compacting, projecting, mining) and transfer (flow, sharing, alert, push). Alavi (2001) presents also 4 stages of KLC which are knowledge creation, storage/retrieval, transfer and application. Sağsan (2006) defines 5 basic steps of KLC in hierarchical order: creating, sharing, structuring, using, and auditing knowledge.

Bergeron (2003) adds to KLC last step, which is knowledge disposal. Stages if his KLC are: creation/acquisition, modification, immediate use, archiving, transfer, translation/ repurposing, user access, and disposal. Each phase of the KMLC is associated with issues, input data, support mechanism, and output data.

Firestone \& Mc Elroy (2003) represent so-called "New KM" which focuses on people,

1 These KM implementation methodology could be: KM Toolkit, Building blocks, P2-KSP, Standardized KM Implementation, APQC Road Map, Nabla Per Partes, K-Stream, Ibermatica, Prorad, On-To-Knowledge, Corma, Know-It (Bureš, 2005), and the one created at University of Hradec Králové KM-Beat-It (Bure $\square$, 2007). In KM-Beat-It methodology, "the analysis phase" defines the initial state of the knowledge processes. The output of this activity is a list of knowledge processes covering the entire life cycle of knowledge from formation to its end. 
processes and social activities; they believe that knowledge processing in human social systems is emergent. Stages of their KLS are: knowledge claim formulation, information acquisition, knowledge integration, knowledge validation, individual and group learning.

Birkinshaw \& Sheehan (2002) suggest KLC represented as a simple S-curve. Along the curve, knowledge progresses through 4 stages: creation, mobilization, diffusion and commoditization.

$\mathrm{Du}$ Preez (2008) presents KLC that, besides above mentioned steps (creation, dissemination, identification, collection, application), includes also obtaining value from knowledge (user obtains value).

Nonaka and Takeuchi (1995) proposed the SECI model which explores knowledge creation through interaction of tacit and explicit knowledge. KM cycle is described as a knowledge spiral that depends on the interaction of tacit knowledge and explicit knowledge leading to 4 modes of knowledge conversion: socialization (S), externalization (E), combination (C), and internalization (I). Socialization converts new tacit knowledge (e.g. shared mental models, technical skills, and shared experience). Externalization transfers tacit knowledge into explicit concepts. Combination converts explicit knowledge into more systematic sets. Internalization embodies explicit knowledge into tacit knowledge.

O'dell et al. (Sağsan, 2006) argue that main steps in KM are organizing, sharing, adapting, using, creating, defining, and collecting of knowledge. However, each of the stages depends on the other and not only exhibit in hierarchical order but also interact between each other (they are interdependent).

The main KLC concepts mentioned above are listed and briefly described in table 2 .

Table 2: Knowledge Life Cycle Concepts.

\begin{tabular}{|c|c|}
\hline Author & Stages of KLC \\
\hline $\begin{array}{l}\text { Probst } \\
(1998)\end{array}$ & $\begin{array}{c}\text { In hierarchical order: Identification, acquisition, development, distribution, } \\
\text { preservation, use of knowledge. }\end{array}$ \\
\hline $\begin{array}{l}\text { Bergeron } \\
(2003)\end{array}$ & $\begin{array}{l}\text { Knowledge creation/acquisition, modification, immediate use, archiving, trans- } \\
\text { fer, translation/repurposing, user access, and disposal. }\end{array}$ \\
\hline $\begin{array}{l}\text { Firestone \& Mc Elroy } \\
(2003)\end{array}$ & $\begin{array}{l}\text { "New KM": knowledge claim formulation, information acquisition, knowledge } \\
\text { integration, knowledge validation, individual and group learning. }\end{array}$ \\
\hline $\begin{array}{l}\text { Birkinshaw \& Sheehan } \\
\qquad(2002)\end{array}$ & S-curve: creation, mobilization, diffusion and commoditization. \\
\hline $\begin{array}{l}\text { Du Preez \& Louw } \\
\text { \& Lutters (2008) }\end{array}$ & $\begin{array}{c}\text { Create knowledge (R\&D), identify \& collect, disseminate, apply, and obtain } \\
\text { value from knowledge. }\end{array}$ \\
\hline $\begin{array}{c}\text { Nonaka \& Takeuchi } \\
\text { (1995) }\end{array}$ & $\begin{array}{l}\text { SECI model (4 modes of knowledge conversion): socialization, externalization, } \\
\text { combination, and internalization. }\end{array}$ \\
\hline $\begin{array}{l}\text { O'dell et al. } \\
\text { (Sağsan, 2006) }\end{array}$ & $\begin{array}{l}\text { Interdependent steps: organizing, sharing, adapting, using, creating, defining, } \\
\text { and collecting of knowledge. }\end{array}$ \\
\hline
\end{tabular}

The concepts differ according to how their authors identify individual process steps of KLC. Nonaka \& Takeuchi (1995) formed the SECI model that depends on the interaction of tacit knowledge and explicit knowledge. This approach differs greatly from others. Mostly, authors describe KLC process as an addition to particular steps in contrast with the others. For example, Firestone and Mc Elroy (2003) include individual and group learning, Bergeron adds disposal of knowledge, and Du Preez et al. stresses that the user obtains value from knowledge. 
PROBLEMS

OF MANAGEMENT

IN THE $21^{\text {st }}$ CENTURY

volume 2, 2011

50

\section{Discussion on Possibility of Analyzing KLC in Automotive Industry}

Only few industries rely on knowledge management more than the automotive sector. This field is growing rapidly as globalization continues to introduce new opportunities and increases competition among companies. Companies try to differentiate themselves in product development and diversification, innovation, and decreasing product life cycle times etc. (Thiebus, 2006). As Sukumaran (2009) argues, "cars fitted with best designs, precision engineering, use of the state of the art technology, IT-driven, heightened safety standards, economically produced, reliability and robustness in performance, high fuel efficiency and ecofriendliness, are no longer a taste of luxury".

If a company is to maintain its success in any market, especially a global one, it is necessary that its processes are among the best available. For supply chains in the automotive industry is specific "knowledge sharing". To ensure effectiveness of shared knowledge it is necessary to apply not only fractional best practices, but the "packages of knowledge" (Švarcová, 2008) as was shown in case studies from the field of automotive industry (MacDuffie, 1995); (Milgrom, 1992); (Sako, 1996).

Although companies can generate value for themselves at every stage, no company can realistically aim to be active in all stages of the KLC. Despite this fact, KLC models have already been usefully developed as a tool for thinking about products and technology. Moreover, the idea that knowledge changes form as it diffuses through a population is also well established. (Birkinshaw, 2002). Nevertheless, there is a need to propose and develop the concept of the KLC in detail as the practical implications of the KLC have not been discussed sufficiently yet. Defining the stages of knowledge life cycle helps to structure the knowledge management process in logical phases. It also suggests effective points for interventions and provides a tested framework for diagnosing the sources of knowledge problems.

Designing a new car requires high levels of expertise and knowledge. It is extremely difficult to codify it due to the fact, that a car is made up of multiple interdependent systems, and the way they interact cannot be entirely predicted. Moreover, in the automotive industry, it is usual for companies to have several vehicle design projects running in parallel, with some degree of stages in their delivery times (Siemieniuch, 1999) and hence it is obviously crucial to manage knowledge during all stages of "product life cycle" (PLC). The life cycle of a car represents the whole process from extraction and processing of raw materials, production of materials and the vehicle, its sale and use, to its disposal, which represents the end of the life cycle of a vehicle. Most of the activities during product life cycle are performed in isolation with few information exchanges. The motivating factor to consider this issue is the fact that data from this process can be exploited in the generation of valuable knowledge to help managers in improving specific aspects of their activities for products of the same family (Bufardi, 2008).

\section{Conclusions}

In this article, the attention is focused on the "knowledge life cycle" approach and concepts that deals with it. Most of the concepts are similar and describe KLC as a process that consists of several stages; only Birkinshaw \& Sheehan (2002) present KLC as a simple Scurve. However, authors usually add particular steps that differ from others, such as individual and group learning from knowledge, obtaining value from knowledge, and knowledge disposal at the end of the process. Moreover, Nonaka \& Takeuchi (1995) formed the SECI model that depends on the interaction of tacit knowledge and explicit knowledge. The concept of KLC can be a powerful tool for understanding how ideas are transformed into commercial products and services, and in view of this, it is desirable to propose and develop a concept of the KLC in detail. Therefore, possibility of KLC analysis was discussed as this industry is the subject of author's research. 
On one hand, the automobile industry is a source of economic growth and prosperity (due to manufacturing thousands of new cars per year). On the other hand, a problem arises concerning handling used and insufficient cars, which are great in numbers. It is deemed essential to consider not only how to dispose of the old vehicles, but also how to design the vehicle in the research \& development stage so that it would be possible to recycle it to $95 \%$ recycle quota. Thus, managers and designer need to manage knowledge effectively during its life cycle. Therefore it is particularly important to consider, besides KLC approach, also so called "product life cycle" (PLC) as was discussed previously.

Currently, environmental considerations are factored into every aspect of a product's sustainability and as the pressure of thinking 'green' increases; the automotive industry is no exception. It is deemed essential to consider not only how to dispose old vehicles, but also how to design the vehicle in the research \& development stage so that it would be possible to recycle them to $95 \%$ recycle quota, a factor that should be adopted in 2015 by EU countries. Including $\mathrm{KM}$ tools in company environmental management could give rise to "environmental knowledge management" (EKM). EKM systems use knowledge to improve corporate environmental performance by lowering the information barrier (e.g. reduction of search costs involved in finding information) that prevents organizations from realizing environmental opportunities (Wernick, 2003). Environmental consideration is associated with "materials flow analysis" (MFA) and "life-cycle assessment" (LCA) that identify the stocks and flows of physical resources, and thus formalize industrial ecology in a business setting. LCA is a measurement tool used to provide information about the environmental performance of products over their life cycle, from the very first step, where the raw materials are extracted, to the last step, where the product is finally disposed off. Companies, however, still do not deal systematically with non-desired outputs (pollution of land, air, water...) and what happens to the products after their expiry time, and the information provided often do not correspond to reality. In view of the above, it would be challenging to come up with a proposal for a study that would focus on monitoring the energy and financial requirements of automobile production in the Czech Republic, starting from the extraction of natural resources, including the actual industrial production and consumption during operation, to disposal of the car wreck.

\section{Acknowledgements}

The article was supported by the "Student Grant Competition" at University of Pardubice - the project "Science and research activities supporting the program Economics and Management" - SGFES03/2011.

\section{Footnotes}

1 Adapted from Gottschalk (2005).

\section{References}

Alavi, M., Leidner, D. (2001). Knowledge management and knowledge management systems: conceptual foundations and research issues. MIS Quarterly, Vol. 25, No. 1, p. 107-136.

APQC, American Productivity and Quality Center (2011). Retrieved 13/09/2011, from <http://www. apqc.org/>.

Apostolou, D., Mentzas, G. (1999). Managing Corporate Knowledge: A Comparative Analysis of Experiences in Consulting Firms. Knowledge and Process Management, Vol. 6, No. 3-4, p. 129-138.

Awad, M. A., Ghaziri, H. M. (2003). Knowledge Management. Prentice Hall: New Jersey.

Bergeron, B. (2003). Essentials of Knowledge Management. John Wiley \& Sons, Inc.: New Jersey. 
PROBLEMS

OF MANAGEMENT

IN THE $21^{\text {st }}$ CENTURY

Volume 2, 2011

Birkinshaw, J., Sheehan, T. (2002). Managing the Knowledge Life Cycle. MIT Sloan Management Review. Fall 2002, Vol. 44, No. 1.

Borghoff, U. M., Pareschi, R. (1997). Information Technology for Knowledge Management. Journal of Universal Computer Science, Vol. 3, No. 8, p. 835-842.

Bufardi, A., Kiritsis, D., Xirouchakis, P. (2008). Generation of Design Knowledge from Product Life Cycle Data. In Bernard, A., Tichkiewitch, S. Methods and Tools for Effective Knowledge Life-CycleManagement. Berlin: Springer, p. 375-389.

Bureš, V. (2005). KM-Beat-It: Metodika zavádění znalostního management. E+M Ekonomie a Management, Vol. 8, No. 7, p. 36-50.

Bureš, V. (2007). Znalostní management a proces jeho zavádění: průvodce pro praxi. 1. ed. Grada Publishing, a.s.: Praha.

Draghici, A., Draghici, G. (2008). Building a Knowledge Share Culture in a Virtual Organization: Case Study for VRL-KCiP NoE. Bernard, A; Tichkiewitch, S. Methods and Tools for Effective Knowledge Life-Cycle-Management. Berlin: Springer, p. 45-60.

Du Preez, N., Louw, L., Lutters, E. A (2008). A Knowledge Network Approach Supporting the Value Chain. Bernard, A; Tichkiewitch, S. Methods and Tools for Effective Knowledge Life-Cycle-Management. Berlin: Springer, p. 159-168.

Ferreira, J. (2007). Knowledge management in automobile industry. Retrieved 13/09/2011, from http:// www.deetc.isel.ipl.pt/matematica/jf/2007/mexico1.pdf.

Firestone, J. M., McElroy, M. W. (2003). Key Issues in the New Knowledge Management. Elsevier Science: Burlington.

Fischer, G., Ostwald, J. (2001). Knowledge Management: Problems, Promises, Realities, and Challenges. Intelligent Systems and their Applications, IEEE, Vol. 16, Iss. 1, p. 60-72.

Glaser, R. (1998). Measuring The Knower: Towards A Theory of Knowledge Equity. California Management Review, Vol. 40, No. 3, p. 175-194.

Gottschalk, P. (2005). Strategic knowledge management technology, Idea Group Publishing: Hershey, $\mathrm{Pa}$, USA.

Mac Duffie, J. P. (1995). Human resource bundles and manufacturing performance: organizational logic and flexible production systems in the world auto industry. Industrial and Labor Relations Review, Vol. 48, No. 2, p. 197-221.

Mezgár, I. (2006). Integration of ICT in smart organizations. Hershey PA, USA: IGI Publishing.

Milgrom, P., Roberts, J. 1992. Economics, Organization and Management. Prentice-Hall: NY.

Nonaka, I., Takeuchi, H. (1995). The Knowledge-Creating Company. Oxford University Press: New York, USA.

O'Leary D. E. (1998). Knowledge management systems: converting and connecting. Intelligent Systems and their Applications, IEEE, Vol 13, Iss. 3, p. 30-33.

OECD (2010). OECD Factobook 2010.

Polanyi, M., Sen, A. (2009). The Tacit Dimension. Reissue edition. University of Chicago Press: Chicago.

Probst, G. J. B. (1998). Practical Knowledge Management: A Model That Works. Little, A. D. Prism, Vol. 2, p. 17-29.

Ribière, V. M., Román, J. A. (2008). Knowledge Flow. Jennex, M. E. Knowledge Management Concepts, Methodologies, Tools and Applications. Hershey: Information Science Reference, p. 1086-1095. 
Sağsan, M. (2006). A New Life Cycle Model for Processing of Knowledge Management. 2nd International Conference on Business. Turkey: Management and Economics in İzmir, 2006. p. 1-9.

Sako, M. 1996. Suppliers' association in the Japanese automobile industry: collective action for technology diffusion. Cambridge Journal of Economics, Vol. 20, No. 6, p. 651-671.

Siemieniuch, C. E., Sinclair, M. A. (1999). Organizational aspects of knowledge life cycle. International Journal of Human-Computer Studies, Vol. 51, p. 517-547.

Sukumaran, S., Shetty, M. V. (2009). Knowledge Management in Automobile: Application of a Value Chain approach using KM Tools. Institute of Electrical and Electronics Engineers.

Švarcová, J. (2008) Best practices firem a jejich transfer. International Conf. for 15th anniv. of Faculty of Business and Management Brno TU. Brno: VUT. Fakulta podnikatelská, p. 109-116.

Thiebus, S., Berger, U. (2006). Knowledge Management for Dynamic Automotive Networks. IFIP International Federation for Information Processing, Vol. 224, p. 591-598.

Wernick, I. (2003). Environmental Knowledge Management. Journal of Industrial Ecology. Vol. 6, No. 2, p. 7-9.

Wiig, K., De Hoog, R., van der Spek, R. (1997). Supporting Knowledge Management: A Selection of Methods and Techniques. Expert Systems with Applications, Vol. 13. No. 1, p. 15-27.

Wu, W. W., Lee. Y. T. (2007). Selecting knowledge management strategies by using the analytic network process. Expert Systems with Applications, Vol. 32, p. 841-847.

Advised by Peter Mikulecký, University of Hradec Králové, Hradec Králové, Czech Republic

Received: September 15, 2011

Accepted: November 30, 2011

Jana Ďurišová

Ing., PhD. Candidate, University of Pardubice, Studentská 84, 53210

Pardubice 2, Czech Republic.

E-mail: Jana.Durisova@upce.cz

Website: http://www.uni-pardubice.cz 